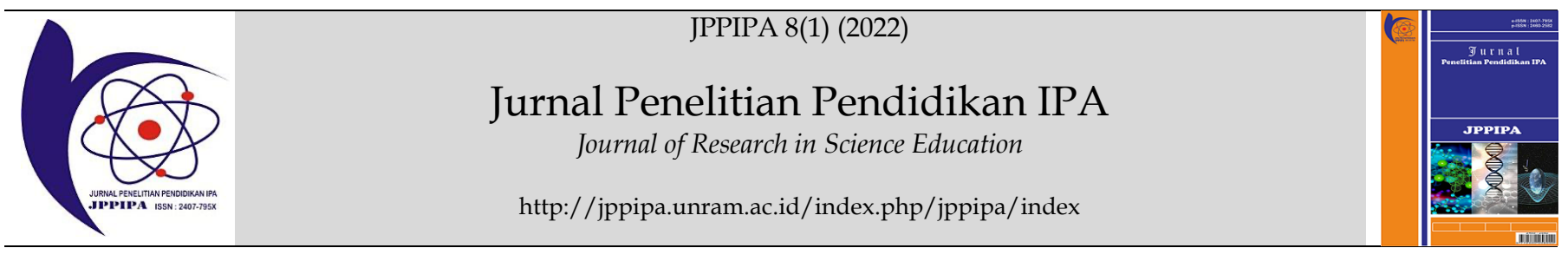

\title{
The Influence of the Use of the Approach of Blended Learning Model Rotation Based Moodle on Motivation and Cognitive Abilities of Students in the Subjects of Physics
}

\author{
Ulan Dari ${ }^{*}$, A. Halim²*, S. Ilyas ${ }^{3}$ \\ ${ }^{1}$ Department of Science Education, Graduate School, Universitas Syiah Kuala, Banda Aceh, Indonesia \\ 2 Department of Physics Education, Faculty of Teacher and Educational, Universitas Syiah Kuala, Banda Aceh, Indonesia \\ ${ }^{3}$ Department of Physics, Faculty of Science and Mathematics, Universitas Syiah Kuala, Banda Aceh, Indonesia
}

DOI: $\underline{10.29303 / \text { jppipa.v8i1.1100 }}$

\section{Article Info}

Received: November 16, 2021

Revised: December 29, 2021

Accepted: January 13, 2022

Published: January 31, 2022

\begin{abstract}
Students' motivation to learn is the main aspect to achieve student success. Based on the results of observation and interview, the learning motivation of students in SMA Negeri 2 Kutacane is still relatively less, so the impact on the low cognitive ability of the students. The purpose of this study is to see the influence of the approach blended learning type station rotation on differences in motivation and cognitive abilities after the study. This research use approach uses quasi-experiments design pretest-posttest control group design. The population of this research is all students of class XI, the sample taken is of class XI IPA 2 as the experimental class and XI IPA 3 as the control class. Using a data collection instrument sheet, questionnaires, and interviews to measure the motivation to learn and use the instrument on a test to measure the cognitive abilities of the students. The results of data analysis using t-test (independent sample t-test) show the differences in motivation and cognitive abilities of students with a significance of $0.000<0.05$ means there is a significant difference between the motivation and ability of cognitive control and experimental classes. Therefore, it can be concluded that there is an influence of the use of the approach blended learning type station rotation motivation and cognitive abilities of the students.
\end{abstract}

Keywords: Blended learning; Rotation; Motivation; Cognitive ability

Citation: Dari, U. ., Halim, A., \& Ilyas, S. (2022). The Influence of the Use of the Approach of Blended Learning Model Rotation Based Moodle on Motivation and Cognitive Abilities of Students in the Subjects of Physics. Jurnal Penelitian Pendidikan IPA, 8(1), 195-202. https://doi.org/10.29303/jppipa.v8i1.1100

\section{Introduction}

The learning process involves the application of information and communication technology (ICT) that can accelerate students' understanding of the material studied and facilitate the adaptation of students to the progress of technology (Tapilouw \& Wclouds, 2008; Sukhbaatar, et al., 2019). Three categories of the learning process involve technology intensively, that is e-learning, blended learning, and distance learning (Kumar, 2008, Owston, et al., 2019). Of the three categories, the model of blended learning is widely used (Siew, 2015). Blended learning is a combination of learning face-to-face and online learning. The purpose of the merger of the two methods is to create an atmosphere of learning that is active, student-centered learning, and interaction between students in the learning process (Garrison, 2004; Allen, et al., 2007; Blankson, et al., 2014; Castro \& Correa, 2021; Prasad, et al., 2018). In the method of blended learning, processes digest the information that occurs formally and informally. Aside from the learning process being guided by the teacher at face-to-face and online sessions, student knowledge can be coupled with leveraging technology and media available over the internet. This helps students to learn anywhere and anytime, allowing students to access learning activities, increase the interaction between students, and increase 
student engagement in getting the learning materials (Bliuc, 2010). The approach of blended learning is in accordance with the methods of 21st-century learning because it emphasizes the student's ability to learn through a student-centered approach.

Research on the approach of blended learning has been done by some researchers. as Kang and Kim (2021) found that the use of the approach of blended learning provides increased knowledge, problem-solving ability, and satisfaction of learning among students, also promotes self-directed learning, and proved to be effectively used to obtain better learning outcomes. Alsalhi, et al., (2019) and Law, et al., (2019) also found that the use of the approach of blended learning provides a significant influence on student achievement and cognitive abilities of students. Harahap, et al., (2019) stated that with the use of blended learning students is required to learn the subjects individually, the students are personally expected to build their understanding of the content of the material, students are also required to actively perform activities of science such as interpretation, predictions, create a hypothesis, ask questions, apply concepts, planning research and communicate research results.

In the run method of blended learning, teachers need to prepare the methods, media, and teaching materials that support the learning process. In the process of learning, the teacher should be proactive in looking for innovative ways to meet the learning needs of students. Teachers change the learning activities and are more active with the approach of creative teaching to facilitate students to understand the teaching materials, increase the interaction and engagement of students while studying. With such involvement, students have the drive and motivation to learn and be able to hone their cognitive abilities (Astalani, et al., 2020; Naimnule, et al., 2016; Ehsanifard, et al., 2020).

Motivation is an influential factor in a situation of being teaching. Success learning depends on whether students are motivated or not (Riyadi \& Sayyidia, 2020). Students ' motivation can be increased through the approach of blended learning. Albiladi and Alshareef, (2019) stated that motivating students to interact and engage in the learning process is built by the presence of the power of blended learning which is based on the second use of teaching methods effectively. It is in line with the results of research conducted by Mutmainnah and Suswandari, (2020) that implementing blended learning can increase the learning motivation of students. Other research suggests that the use of the approach of blended learning gives a great effect on engagement and motivation to learn (Saritepeci \& Cakir, 2015).

Cognitive ability is an aspect of mental activity or brain and also the activities of the process of thinking
(Nirbita, 2020). Efforts to hone the cognitive ability of the students are done by involving the various activities that need to be done by students in each of the learning processes in order to obtain good results (Naimnule, et al., 2016). Blended learning is an approach that gives freedom to the students in the search for the needed information from a variety of sources, giving an opinion, doing something related to the lesson, and summed up beside the found (Fatkhulloh \& Haryanto, 2020). Some of the research on cognitive ability has also been done by previous researchers. Alfalfa, et al., (2018) showed the use of the approach of blended learning is effective to improve student learning outcomes. Next on the research conducted by Nomyssova, et al., (2019), students who acquire the methods of blended learning tend to get better learning outcomes, one of which cognitive abilities are increased.

Motivation and cognitive abilities of students increased with the implementation of the approach of blended learning, where students are expected to be engaged when the learning process takes place. Most of the research conducted previously using literature study (Mutmainnah \& Suswandari, 2020; Christina, et al., 2019; Ayob, et al., 2020; Sulistyorini, 2021), method development (Alfalfa, et al., 2018), applied at the university level (Govindaraj \& Silverajah, 2017; Mahalli, et al., 2019) and is still rarely applied at the level of upper secondary school (Nugraha, 2019). Therefore, it is necessary to do research using the approach of blended learning with the type of station rotation against motivation and cognitive abilities of the students. Based on the results of observations conducted in SMA Negeri 2 Kutacane, the activity of student learning is still relatively low, in the sense that the youngsters tend to be passive in learning. Management activities of internet-based learning are not effective, and not to the development of learning activities that strengthen the use of online media in learning so that freedom of thought and openness of information is very minimal. Based on the results of interviews with teachers of physics, the cognitive ability of students after the material is finished, then given the exercise or examination, of the 29 students only about $17 \%$ that get the value good. Then the results of the review the average value UN on the material the sound waves, for the years 2018 and 2019 from the Center for Educational Assessment, the Ministry of Education and Culture, that the results of the average value obtained by students on the material of the sound waves in 2018 are 31.59 and 2019 is 41.93 . For that, this study is expected to be able to measure the influence of the approach of blended learning type of station rotation on motivation and cognitive abilities of students in SMA Negeri 2 Kutacane. 


\section{Method}

This study focuses on the use of the approach of blended learning type of station rotation in the experimental class and conventional method on the control class to see the effect of both methods on motivation and cognitive abilities of the students. Approach the research used is quasi-experiment, with the design of Non - equivalent Control Group PretestPosttest Design which is a design of pretest and posttest are carried out on two groups of the study sample. The research design can be seen in Table 1 .

Table 1. The Non-Equivalent Control Group Design

\begin{tabular}{llll}
\hline Subject & Pretest & Treatment & Posttest \\
\hline Experimental & Y1 & X1 & Y2 \\
Control & Y1 & X2 & Y2 \\
\hline
\end{tabular}

Description:

(Sugiyono, 2018)

$Y_{1}=$ Pretest.

$\mathrm{Y}_{2}=$ Posttest.

$\mathrm{X}_{1}=$ Treatment approach blended learning model station rotation.

$\mathrm{X}_{2}=$ Treatment with learning conventional

The researchers chose one type of sampling nonprobability sampling that is by using the technique of purposive sampling. Purposive sampling is done because of some consideration or a particular purpose. The selection of the sample is based on purposive sampling depending on the criteria used, then it is determined in advance the criteria of the sample are taken. The researchers chose class XI IPA 2 as the class of experiments and class XI IPA 3 as the control class because based on the results of the data pretest class XI IPA 2 and XI IPA 3 has an average value that is not significantly different.

To get the data needed, there are several ways yang can do that.

1. Preparation phase: Researchers make a research instrument and test about the test to determine the quality of the instrument is made.

2. Implementation phase: the researcher gives a pretest to determine the cognitive abilities of a student, then treatment is given on the research respondents, by applying the model of blended learning station rotation in the experimental class and conventional method on the control class. Then give the posttest and questionnaire in order to get the data, motivation, and cognitive ability of the students after being given treatment.

3. Stage conclusion: researchers analyzed the percentage of the questionnaire of learning motivation of students using Microsoft Excel and calculate the results of the tests of cognitive abilities of students using test independent sample t-test using SPSS version 20.0. A general overview of the application of station rotation can be seen in Figure 1.

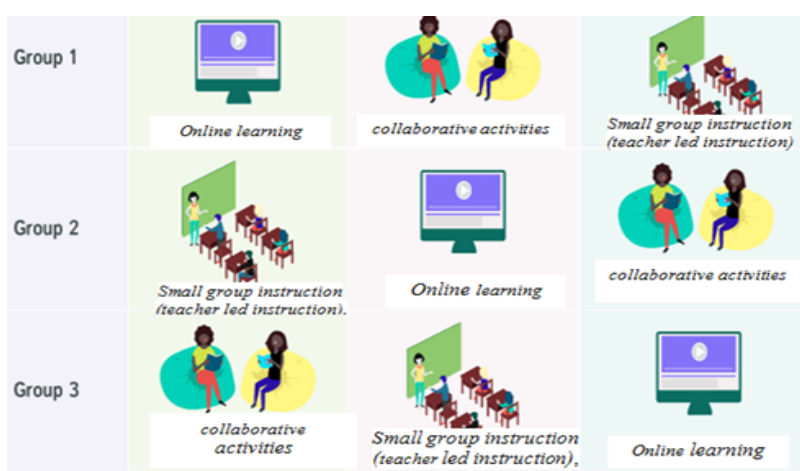

Figure 1. Flow Research Station Rotation

\section{Data analysis motivation}

Data this study derived from a questionnaire distributed at the class of experiments that XI IPA 2 consisted of 29 students and XI IPA 3 consists of 27 students. A questionnaire containing 21 questions related to students motivation to learn. Data analysis techniques were performed on the questionnaire with scoring the students ' answers that are based on the scale of Likert scale, with 5 answer options such as it is presented in Table 2. which are analyzed with the help of Microsoft excel.

Table 2. Score the questionnaire of learning motivation of students

\begin{tabular}{ll}
\hline Alternative answer & Score of declaration \\
\hline Strongly disagree & 1 \\
disagree & 2 \\
Undecided & 3 \\
Agree & 4 \\
Strongly agree & 5 \\
\hline
\end{tabular}

Furthermore, the obtained score is calculated in the form of a percentage using equation 1 .

$x=\frac{a}{b} \times 100 \%$

Description:

$\mathrm{x}=$ the value of the individual

$\mathrm{a}=$ score obtained

$\mathrm{b}=$ maximum score

After the calculated score per individual then determined the average motivation of all students in a class to determine the level of learning motivation of students overall by equation 2 .

$\bar{x}=\frac{\sum n}{m} 100 \%$

Description: 
$\bar{x}=$ Average motivation of students in one class

$\Sigma_{\mathrm{n}}=$ The amount of the percentage score of the individual

$\mathrm{m}=$ Persentase maximum score

Furthermore, the final results obtained in qualitative into the assessment criteria. The results obtained in the form of quantitative data will be converted into the data qualitative each interval like listed in Table 3.

Table 3. Criteria of learning motivation of students

\begin{tabular}{ll}
\hline Percentage $(100 \%)$ & Criteria \\
\hline $0-20$ & very low \\
$21-40$ & Low \\
$41-60$ & Being \\
$61-80$ & High \\
$81-100$ & very high \\
\hline
\end{tabular}

The analysis of the cognitive abilities of students.

The analysis of the cognitive ability test using the help of the program SPSS version 20.0, with t-test twosample unpaired namely independent-samples t-test with a 0.05 significance. Test independent-samples ttest is used to see the difference in the results of tests of cognitive abilities of students of the experimental class and the control class.

\section{Result and Discussion}

Based on the distribution of a questionnaire given to students, obtained the percentage of the results of the learning motivation see overall on the control class is in the category enough of $61 \%$. Data on the percentage of learning motivation of students in the control class is presented in Figure 2.

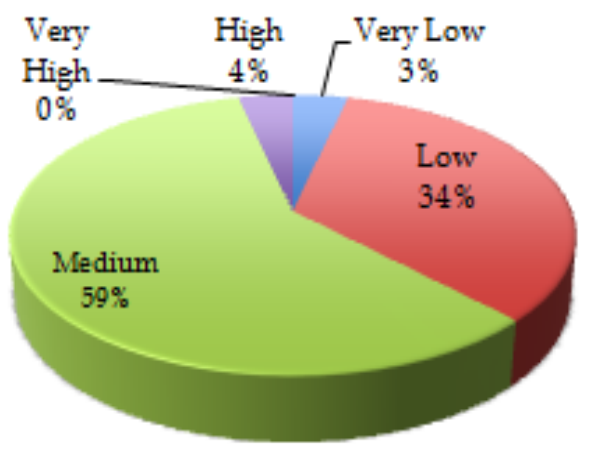

Figure 2. Motivation student learning grade control

Based on Figure 2. the motivation of the students in the control class after doing the research, more than half of the students obtain the results of motivation with the criteria being those 16 students. 1 student has motivation in the category of very low, 9 students in the low category, and 1 student in the high category. Then the distribution of the questionnaire is given in the experimental class, the percentage of the results of the learning motivation of students as seen in Figure 3.

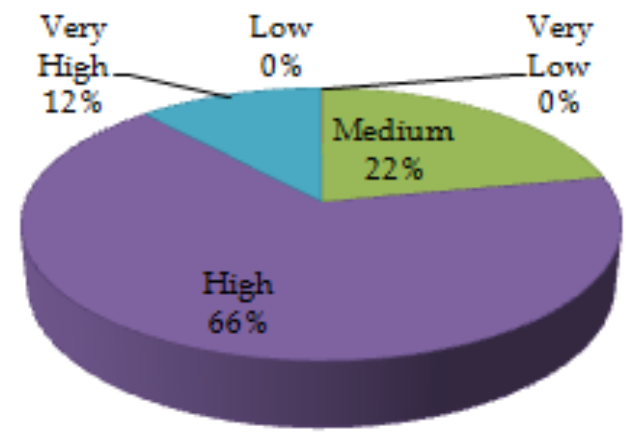

Figure 3. Motivation to learn students of the experimental class

Based on the results analysis of the data in Figure 3 above it is seen that there are differences in learning motivation of students between the control class and the experimental class. Based on the fact that the learning process takes place, the difference in motivation between the two classes because the students in the experimental class using the method of blended learning type of station rotation feel happy and also more active in the learning process. Through the approach of blended learning with the type of station rotation this, students also get a lesson online using the app Moodle. The learning process goes with question and answer, discussion together so that students are directly involved during the process of teaching and learning and satisfaction for students also the quality when learning met. It is supported by a statement Astalini, et al (2019) stated that to improve students' motivation to learn, students must do something related to learning so that students are more motivated to learn. The Figure 4 until 6 shows the learning motivation of students of the experimental class by using a blended learning approach type of station rotation.
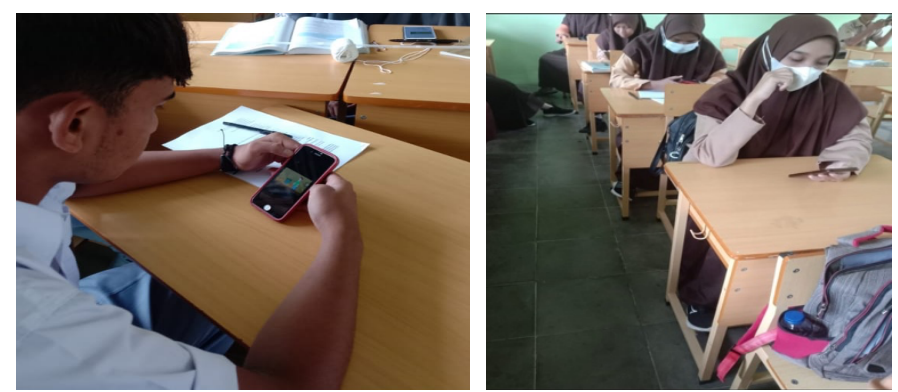

Figure 4. Learning on station online 

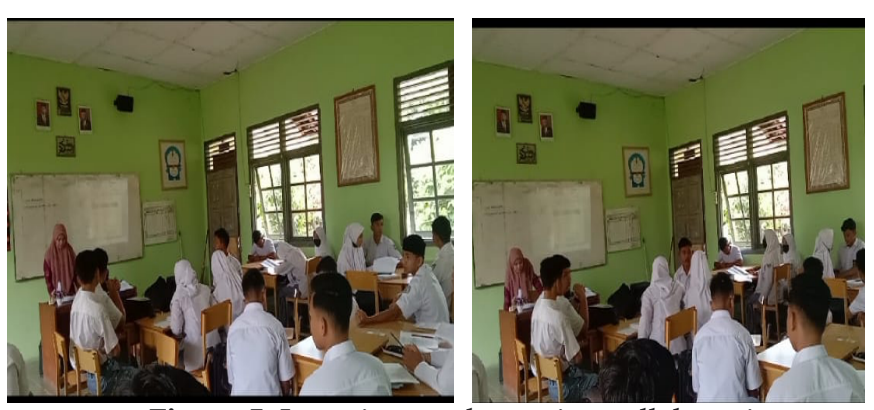

Figure 5. Learning on the station collaborative
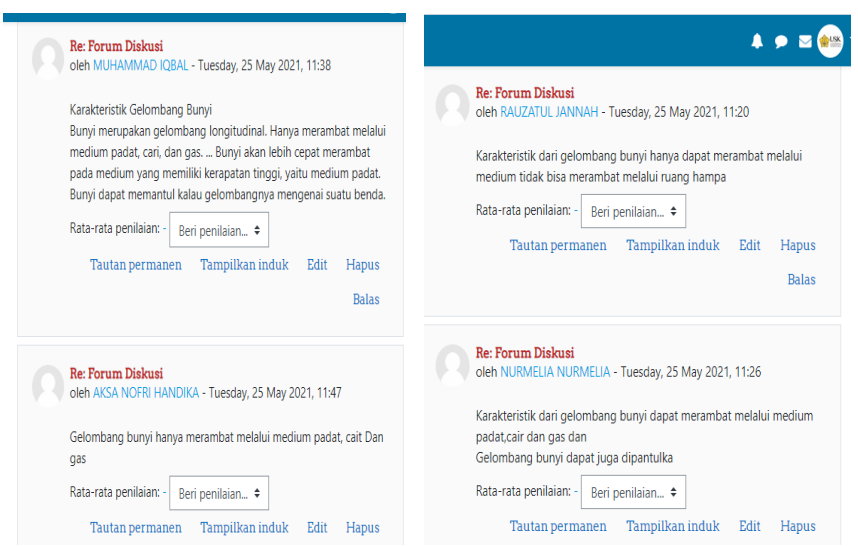

Figure 6. Station lead instruction

Blended learning type of station rotation to change the learning that was previously only learned by listening to a teacher in front of the class to be a mix between a variety of media, learning resources, and also many different learning. Can also be likely to increase the interaction between teachers and students, students with students, as well as students with learning content. In line with that in the experimental class students acquire learning methods using the blended learning type of station rotation that increases motivation in learning because students interact during the learning process. Fatkhulloh \& Haryanto, (2020) states that the approach of blended learning can stimulate the students to improve the learning activities and their efforts in exploration and outlines the required information. Increased motivation in the experimental class is supported by the results of the study are Considered and Suswandari (2020) on his research, with the implementation of the station rotation blended learning can increase the learning motivation of students.

The results of the analysis of the data obtained from the results of tests of cognitive abilities of students for the class of controls and class experiments seen in figure 7 .

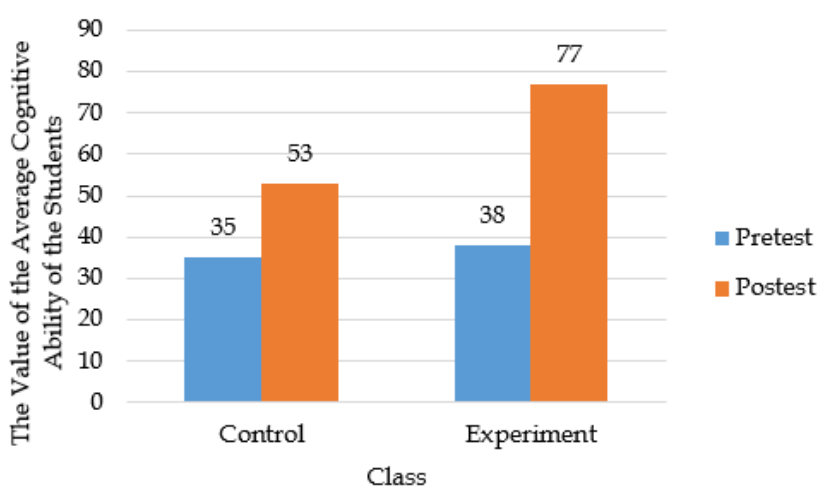

Figure 7. The average cognitive ability of the students in the control class and experiment

Based on Figure 7. the results of the average cognitive abilities obtained prove that the influence of the use of learning methods is given. In the experimental class using the approach of blended learning type of station rotation for the cognitive ability of the students is higher than control class by using conventional methods. The increase in the cognitive abilities of the students in the experimental class due to the method used involves the students active while learning.

The process of learning in the experimental class using the approach of blended learning type station rotation combines the three stages and is rotated faceto-face. This stage consists of teacher led instruction, online instruction and collaborative activities. On the stages of teacher-led instruction students carry out learning activities led by the teacher. In this research, students are guided to open a forum for discussion and then answer the questions on the forum. On the online instruction students watched the videos of learning, reading, listening learning materials and also answered the question on the video. Then the last stages of the collaborative activities each student aright join to perform collaborative. At this stage the students complete the worksheet learners.

There is a step-by-step process of learning the experimental class with the use of a blended learning type of station rotation of the properties studied by those students directly involved in the study. In accordance with the statement Naimnule, et al., (2016) in sharpening cognitive abilities of students, in each of the learning process involves a range of activities that need to be done by students in order to obtain good results.

While differences occur in the control class that follow the conventional learning models. Students tend to be passive, both in the cognitive and psychomotor. Space for students is very limited to explore and express their thoughts in the form of creativity. The lack of opportunity for students to gather information and 
investigate something that makes the activity of thinking of students decreased. As a result, cognitive abilities of students who take conventional learning models tend to be low compared with the experimental group. Students cognitive per indicator between the classes of experiment and control class through the analysis of the equations of $\mathrm{N}$-gain are presented in Table 4.

Table 4. N-gain of each indicator of the cognitive.

\begin{tabular}{lllll}
\hline Indicators of & $\mathrm{N}$-gain Control & Category of & N-gain experimental & Category \\
\hline Given & 0.47 & Medium & 0.31 & Medium \\
Understanding & 0.40 & Medium & 0.65 & Medium \\
Apply & 0.19 & Low & of 0.53 & Medium \\
Analyze & 0.29 & Low & of 0.70 & Medium \\
Evaluates & 0.38 & Medium & 0.63 & Medium \\
Make & 0.04 & Low & of 0.66 & Medium \\
\hline
\end{tabular}

Table 4. generally shows improved cognitive abilities of the students in the control class and the experimental class in every aspect increased in the medium category. Cognitive abilities on each of the indicators did not show differences on the criterion of $\mathrm{N}$-gain. But has an average value different from each indicator. Indicators considering the average values are relatively the same, namely 81.48 to the control class and 81.03 for a trial class. This is because the students have been accustomed to learning on the question at the level of $\mathrm{C} 1$. In accordance with the statement of Nabilah, et al (2020) the learning process is most often done only to train the aspect of considering the students. It can be concluded based on the results of data analysis that at the level of remembering (C1) students were able to recall the theories associated with the sound wave.

\section{Conclusion}

Based on the results and discussion can be concluded that there are differences in learning motivation and cognitive abilities of the students significantly between the groups of students who follow the learning blended station rotation and the group of students who take conventional learning models. Educational institutions must be constantly emphasized the approach of a mixture of learning through the installation of a learning management system with the internet to allow effective learning through technology, especially in developing countries. Recommendations for school teacher who has not yet apply the method of blended learning that can try to apply the method with the approach of blended learing the school. Then recommendations for further research based on the approach of blended learning, because a small number of students felt disappointed with the couples in the group, the researchers should pay more attention to it. Teachers should pay attention to the dissatisfaction among the students.

\section{Acknowledgments}

Thanks to the leadership and the teaching staff at SMA Negeri 2 Kutacane who have given their time and service facilities for research and thanks to the lecturers who have guided in completing this article.

\section{References}

Albiladi, W. S., \& Alshareef, K. K. (2019). Blended learning in English teaching and learning: A review of the current literature. Journal of Language Teaching and Research, 10(2), 232-238. http://dx.doi.org/10.17507/jltr.1002.03

Alfalfa, M. F., Agung, A. G., \& Tegeh, I. M. (2018). Pengembangan Blended Learning Tipe Stationrotation Model Pada Mata Pelajaran Bahasa Indonesia Kelas X Multimedia. Jurnal Edutech Undiksha, 6(2),

222-232. http://dx.doi.org/10.23887/jeu.v6i2.20296

Alsalhi, N. R., Eltahir, M. E., \& Al-Qatawneh, S. S. (2019). The effect of blended learning on the achievement of ninth grade students in science and their attitudes towards its use. Heliyon, 5(9), e02424.

https://doi.org/10.1016/j.heliyon.2019.e02424

Astalini, D., Darmaji, D., Pathoni, H., Kurniawan, W., Jufrida, J., Kurniawan, D., \& Perdana, R. (2019). Motivation and attitude of students on physics subject in the middle school in indonesia. International Education Studies, 12(9), 1526. http://dx.doi.org/10.5539/ies.v12n9p15

Ayob, N.F.S., Halim, N.D.A., Zulkifli, N.N., Zaid, N.M., \& Mokhtar, M. (2020). Overview Of Blended Learning: the Effect of Station Rotation Model on Students Achievement. Journal of Critical Reviews, 7(6):320-326.

Bliuc, A. M., Ellis, R., Goodyear, P., \& Piggott, L. (2010). Learning through face-to-face and online discussions: Associations between students' 
conceptions, approaches and academic performance in political science. British Journal of Educational Technology, 41(3):512-524. http://dx.doi.org/10.1111/j.14678535.2009.00966.x

Castro, G.R., \& Correa, D. (2021). Transparency in previous literature reviews about blended learning in higher education. Education and Information Technologies, 1-28. https://doi.org/10.1007/s10639-020-10406-x

Christina, S., Rusijono, R., \& Bachtiar, B. (2019). The Application of Blended Learning's Station Rotation Method in Elementary School's Science Education to Improve Higher Order Thinking Skills. Dinamika Jurnal Ilmiah Pendidikan Dasar, 11(2), 79-85. http://dx.doi.org/10.30595/dinamika.v11i2.5048

Ehsanifard, E., Ghapanchi, Z., \& Afsharrad, M. (2020). The Impact of Blended Learning on Speaking Ability and Engagement. Journal of Asia TEFL, 17(1), 253. http://dx.doi.org/10.18823/asiatefl.2020.17.1.17.2 53

Fatkhulloh, S. (2020, March). Can blended learning replace conventional learning in terms of mastery learning and cognitive attainment. In Journal of Physics: Conference Series, 1511(1), 012025. http://dx.doi.org/10.1088/17426596/1511/1/012025

Garrison, D. R., \& Kanuka, H. (2004). Blended learning: Uncovering its transformative potential in higher education. The internet and higher education, 7(2), 95105. https:// doi.org/10.1016/j.iheduc.2004.02.001

Govindaraj, A., \& Silverajah V.S. G. (2017). Blending Flipped Classroom and Station Rotation Models in Enhancing Students' Learning of Physics, ICETC 2017: Proceedings of the 2017 9th International Conference on Education Technology and Computers. https://dl.acm.org/doi/proceedings/10.1145/317 $\underline{5536}$

Harahap, F., Nasution, N. E. A., \& Manurung, B. (2019). The Effect of Blended Learning on Student's Learning Achievement and Science Process Skills in Plant Tissue Culture Course. International Journal of Instruction, 12(1), 521-538. http://dx.doi.org/10.29333/iji.2019.12134a

Kang, H. Y., \& Kim, H. R. (2021). Impact of blended learning on learning outcomes in the public healthcare education course: a review of flipped classroom with team-based learning. BMC Medical Education, 21(1), $1-8$. https:// doi.org/10.1186/s12909-021-02508-y

Kumar, R. (2008). Convergence of ICT and Education. World Academy of Science, Engineering and https://citeseerx.ist.psu.edu/viewdoc/download ?doi=10.1.1.193.2558\&rep=rep1\&type $=$ pdf

Law, K. M., Geng, S., \& Li, T. (2019). Student enrollment, motivation and learning performance in a blended learning environment: The mediating effects of social, teaching, and cognitive presence. Computers $\mathcal{E} \quad$ Education, 136, 1-12. https://doi.org/10.1016/j.compedu.2019.02.021

Mahalli, J. N., Mujiyanto, J., \& Yuliasri, I. (2019). The Implementation of Station Rotation and Flipped Classroom Models of Blended Learning in EFL Learning. English Language Teaching, 12(12), 23-29. https://doi.org/10.5539/elt.v12n12p23

Mulya, G., \& Lengkana, A. S. (2020). Pengaruh Kepercayaan Diri, Motivasi Belajar Terhadap Prestasi Belajar Pendidikan Jasmani. COMPETITOR: Jurnal Pendidikan Kepelatihan Olahraga, 12(2), 83-94. https://doi.org/10.26858/cjpko.v12i2.13781

Muthmainnah, A., \& Suswandari, M. (2021). Implementasi Station Rotation Blended Learning tehadap Motivasi Belajar dan Pendidikan Karakter Peserta Didik. International Journal of Public Devotion, 3(2), 59-64. https://dx.doi.org/10.26737/ijpd.v3i2.2069

Nabilah, M., \& Stepanus Sahala, H. (2020). Analisis Kemampuan Kognitif Peserta Didik dalam Menyelesaikan Soal Momentum dan Impuls. Jurnal Inovasi Penelitian dan Pembelajaran Fisika, 1(1), $1-7$. http://dx.doi.org/10.26418/iippf.v1i1.41876

Naimnule, L., Oetpah, V., \& Sila, V. U. R. (2016). Peningkatan Aktivitas Dan Hasil Belajar Kognitif Siswa Melalui Penerapan Model Pembelajaran Think Talk Write (Ttw) Di Smuk. Jurnal Pendidikan: Teori, Penelitian, dan Pengembangan, 1(10), 20502053. http://dx.doi.org/10.17977/jp.v1i10.7622

Namyssova, G., Tussupbekova, G., Helmer, J., Malone, K., Mir, A., \& Jonbekova, D. (2019). Challenges and benefits of blended learning in higher education. Retrieved from: https://nur.nu.edu.kz/bitstream/handle/1234567 89/4494/

Nirbita, B. N. (2020). Problem Based Learning with ICT for Student's Cognitive. Jurnal Pendidikan dan Pembelajaran Kimia, 9(2), 46-54. Retrieved from http://jurnal.fkip.unila.ac.id/index.php/JPK/arti cle/view/21147

Niswaty, R., Rusbiati, S., Jamaluddin, J., \& Salam, R. (2017). The Influence of Teacher's Reinforcement for Students Motivation. In International Conference on Education, Science, Art and Technology (pp. 148152).

Retrieved from http://jurnal.fkip.unila.ac.id/index.php/pgsd/art icle/view/13942 
Nugraha, D. M. D. P. (2021). Station Rotation Type Blended Learning Model Against Critical Thinking Ability of Fourth Grade Students. Journal of Education Technology, 4(4), 516-523. http:/ / dx.doi.org/10.23887/jet.v4i4.29690

Owston, R., York, D. N., \& Malhotra, T. (2019). Blended learning in large enrolment courses: Student perceptions across four different instructional models. Australasian Journal of Educational Technology, 35(5), 29-45. https://doi.org/10.14742/ajet.4310

Prasad, P. W. C., Maag, A., Redestowicz, M., \& Hoe, L. S. (2018). Unfamiliar technology: Reaction of international students to blended learning. Computers $\mathcal{E} \quad$ Education, 122, 92-103 https://doi.org/10.1016/j.compedu.2018.03.016

Riyadi, A., \& Alhanif, S. S. (2020). Hubungan Motivasi Belajar dengan Prestasi Belajar Siswa pada Mata Pelajaran Ekonomi Kelas X (Sepuluh) di MA AlQurtubiyyah Nagrak Tahun Pelajaran 2016/2017. As-Syar'i: Jurnal Bimbingan E Konseling Keluarga, 2(1), 104-118. https://doi.org/10.47467/as.v2i1.124

Saritepeci, M., \& Cakir, H. (2015). The Effect of Blended Learning Environments on Student's Academic Achievement and Student Engagement: A Study on Social Studies Course. Education and science, 40(177): 203-216. http://dx.doi.org/10.15390/EB.2015.2592

Sukhbaatar, O., Usagawa, T., \& Choimaa, L. (2019). An artificial neural network based early prediction of failure-prone students in blended learning course. International Journal of Emerging Technologies in Learning (iJET), 14(19), 77-92. https://doi.org/10.3991/ijet.v14i19.10366

Sulistyorini, S. (2018). Infusing Active Learning Strategies Into Station Rotation Model In English Classroom. Conference: Infusing Active Learning Strategies into Station Rotation Model in English Classroom. Retrieved from: https://icsai.org/procarch/10iclei/10iclei-036.pdf

Tapilouw, F., \& Setiawan, W. (2008). Meningkatkan pemahaman dan retensi siswa melalui pembelajaran berbasis teknologi multimedia interaktif. Jurnal pendidikan teknologi informasi dan komunikasi, 1(2), 19-25. 